\title{
ジオシンセティック敷設による粘性土地盤支持力補強の考察
}

\begin{tabular}{cccccc} 
日本大学理工学部 & 正会員 & 峯 & 岸 & 邦 & 夫 \\
同 上 & 正会員 & 巻 内 & 勝 \\
\hline
\end{tabular}

概 要:

本研究は、ジオシンセティック（織布）を用いて室内土層モデル試験を行い、ジオシンセティッ クを地盤表面あるいは地盤中に旉設した場合と、敷設しない場合とについて地盤中の変形を観測・ 解析し、軟弱粘性土とジオシンセティックの摩擦特性試験結果などを踏まえ、既往のTerzaghiの支 持力理論を基本とする支持力算定法の検討に基づき、軟弱地盤に対するジオシンセティック敷設の 支持力補強と地盤変形抑制の効果についてのメカニズムとその評価方法について考察を行った。

その結果、地盤表面の変形を 2 次曲線として近似することによって従来の方法に比べ半径や傾斜 角の算出に個人䛊差の影響を受けないこと、全支持力の中でジオシンセティック敷設によるハン モック的効果の受け持つ割合が大きいこと、地盤中にジオシンセティックを敷設する場合、一定以 深になると敷設効果が発揮できないことなどが明らかとなった。

\section{A Consideration of Geosynthetic-Reinforcement on Bearing Capacity of Cohesive Soils}

\author{
Kunio MINEGISHI \& Katsuhiko MAKIUCHI \\ ( College of Science \& Technology, Nihon University)
}

\begin{abstract}
:
In this study, a series of laboratory two-dimensional model tests were carried out using geosynthetics and cohesive soils. Several geowovens of different tensile strength were laid on the surface of and at the given depth of soft clay ground. The deformation of the ground under strip loadings were observed and the interface friction between geosynthetics and cohesive soil was determined. A mechanism of geosynthetic-reinforcement on the bearing capacity of clay ground was considered and the evaluation method was proposed based on the modified Terzaghi's bearing capacity theory.

As the experimental results, a ground surface deformation can be expressed in the from of a quadratic equation and the radius and the tangent of surface deflection can be taken more accurately than the conventional methods. It was found that the role of hammock's effect is significant. Moreover, it was observed that the reinforcement of geosynthetics did not displayed at the deeper place than a certain laying limit.
\end{abstract}




\section{ジオシンセティック敷設による粘性土地盤支持力補強の考察}

$\begin{array}{ccccc}\text { 日本大学理工学部 } & \text { 正会員 } & \text { 峯 } & \text { 岸 } & \text { 邦 } \\ \text { 同 上 } & \text { 正会員 } & \text { 巻 } & \text { 内勝 彦 }\end{array}$

\section{1.まえがき}

軟弱地盤においてジオシンセティックを敷設した場合、地盤支持力を算定する最も一般的な式は、 Terzaghi の支持力理論を基本とするものである ${ }^{1)}$ 。しかし、この式の適用範囲および式中に存在す る諸パラメータの決定については、経験に頼るところが大きいのが現状である。これを明確にする ために各方面での調査・研究が行われている。

本研究においては、ジオシンセティックを使用した場合の補強メカニズムを検討するため土槽モ デル試験を行いTerzaghiの支持力理論式の適用範囲および式中に存在する諸パラメータの特性およ び設計に関する定数を明確にするために、表面および内部の変形状態、荷重と沈下量の関係、載荷 幅、ジオシンセティックの張力などの影響、ジオシンセティックと粘土の付着力を調べ、それらに ついて考察を行った。

\section{2. 試料および試験方法}

$2-1$ 試料

(1) 粘土試料

今回実験に使用した粘土試料は、市販の粉末状カオリン粘土である。室内で軟弱地盤状態を再現 するため、カオリン粘土を含水比 $w_{0}=80 ， 90 ， 100 \%$ に十分練り返して調整した。このカオリン粘 土の物理的性質およびCBR 值は、表ー 1 に示すとおりである。なお CBR 試験は、JIS A 12112)に基 づき行ったが、極めて低支持力になるため貫入棒等を改良して行った。

(2) ジオシンセティック試料

ジオシンセティックは、引張り強度の異なった3種類 の織布（T-100，T-150，T-200）を用いた。表一2に それらの諸物性を示す。

\section{$2-2$ 試験装置および試験方法}

\section{$2 \cdot 2 \cdot 1$ 摩擦特性試験}

本研究では、ジオシンセティックと粘性土との摩擦 特性を調べるため以下の 3 種類の摩 擦特性試験を行った。

表一 1 粘土試料の物理的性質と CBR

\begin{tabular}{|c|c|c|}
\hline 土粒子の密度 & $\rho:\left(\mathrm{g} / \mathrm{cm}^{3}\right)$ & 2.68 \\
\hline 液性限界 & $w_{\mathrm{L}}(\%)$ & 81.0 \\
\hline 塑性指数 & $I_{P}$ & 53.7 \\
\hline \multirow{3}{*}{ C B R $(\%)$} & $w_{0}=80 \%$ & 0.05 \\
\hline & $w_{0}=90 \%$ & 0.04 \\
\hline & $w_{0}=100 \%$ & 0.03 \\
\hline
\end{tabular}

\section{(1) Type I}

ジオシンセティックを平坦な合板 に接着刘で貼りつけ、その上を試料 土を詰めたせん断箱を滑らせる実験 である。試験条件は、試料土であるカ オリン粘土を初期含水比を前述した3 条件に調整し、それぞれ垂直応力 $\sigma$ 、 $=2.5,5.0,7.5,10 \mathrm{kN} / \mathrm{m}^{2}$ を載荷し てスクリュージャッキにて水平荷重 をかけ水平変位と力計の読みを測定 した。なお、せん断箱は箱自体の自重

表一2 ジオシンセティック試料の諸物性 ${ }^{3)}$

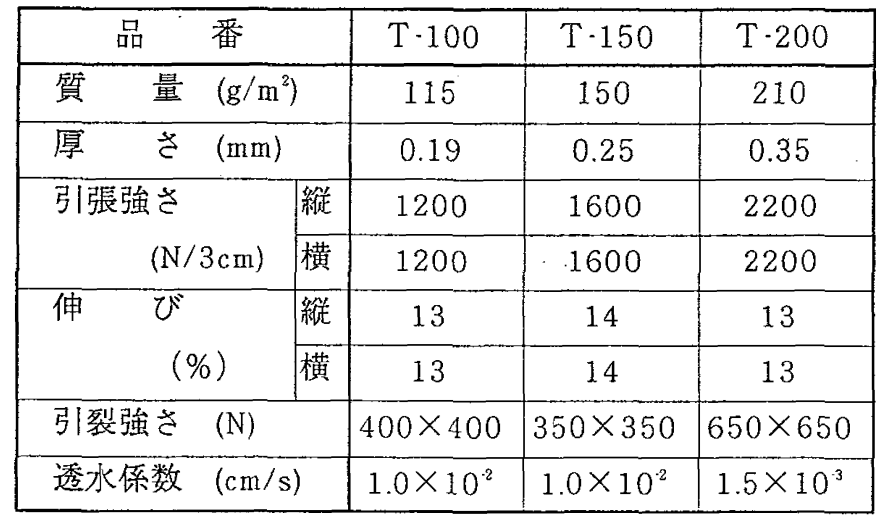


の影響を避けるため木製とし、摩擦抵抗を極力低減するように工夫し、寸法は $300 \times 200 \times 50 \mathrm{~mm}$ とした。

(2) Type II

後述する室内土槽モデル試験で使用する土槽を用いて、試料土とその上に敷設したジオシンセ ティックの摩擦特性を調べた。

土槽（1000×400×510mm）に含水比を $80 \%$ に調整したカオリン粘土を気泡が混入しないよう に詰め、表面を平坦に成形しジオシンセティックを敷設する。ジオシンセティックの中央部に荷重 を載荷板（載荷幅 $2.5,5.0 \mathrm{~mm}$ ) を介して載荷し一方から一定速度 $(1.0 \mathrm{~mm} / \mathrm{sec}$ ) で引抜き、ジオシ ンセティックが動き出した瞬間の荷重を測定した。

(3) Type III

在来型一面せん断試験装置を用いて、せん断箱下箱にダミー供試体にジオシンセティックを接着 剤で貼りつけたものを入れ、上箱に含水比を $80 \%$ に調整したカオリン粘土を空隙のないように詰め、 それぞれ $\sigma_{\mathrm{v}}=50,100,150,200 \mathrm{kN} / \mathrm{m}^{2}$ を載荷して試験を行った。

\section{$2 \cdot 2-2$ 室内土槽モデル試験}

\section{(1) Test I (応力制御型試験)}

図－1に示す側面が強化ガラス製の土槽 $(1000 \times 400 \times 510 \mathrm{~mm})$ に含水比を $80 \%$ に調整したカ オリン粘土を気泡が混入しないように詰め表面にジオシンセティック（T-150）を敷設した場合と しない場合について載荷板を介して所定の載荷荷重を加え、土槽表面および内部の変形量を観測し た。試験条件は、載荷幅 $5.0 \mathrm{~cm}$ の場合は載荷荷重を $100,200,300,400,500 \mathrm{~N}$ 、載荷幅 $2.5 \mathrm{~mm}$ の場合は載荷荷重を $100,150,200 ， 250 ， 300 \mathrm{~N}$ として、ジオシンセティックを敷設した場合は、 襾端に $0,2.5,5.0,7.5,10 \mathrm{~N} / \mathrm{cm}$ の張力を与えた。載荷板に所定の載荷荷重を加え粘土中に貫入 させ、貫入が停止後、土槽表面および内部（埋設 したマーカー）の変位量を测定した。

(2) Test II（沈下量制御型試験）

TestＩと同様に粘土を詰めた土槽の表面および 地盤内部にジオシンセティックを敷設または、敷 設しない場合について、所定量 (40または $80 \mathrm{~mm}$ ) 載荷板を貫入させた時の力計および土槽表面、地 盤内部の変位量を測定した。ジオシンセティック は、T-100，T-150およびT-200を用いた。試験 条件は、載荷幅 $5.0 \mathrm{~cm}$ の場合は、深さ $z=0$ (表面), $25 ， 50 ， 75 ， 100 ， 125 ， 150 \mathrm{~mm}$ に敷設し、表面 に敷設した場合は、ジオシンセティックの両端に $\mathrm{T}=0,2.5,5.0,7.5,10 \mathrm{~N} / \mathrm{cm}$ の張力を与えた。 載荷幅 $2.5 \mathrm{~cm}$ の場合は、梁さ $z=0$ (表面), 25 , $50 \mathrm{~mm}$ に敷設し、表面に敷設した場合は、ジオシ ンセティックの両端に $\mathrm{T}=0,5.0,10 \mathrm{~N} / \mathrm{cm}$ の張力 を与えた。

\section{3. 軟弱地盤の支持力算定法}

軟弱地盤の支持では、ジオシンセティックを用 いると図ー2に示すような張力がシートと地盤と の摩擦力によって得られるか、または人工的に加

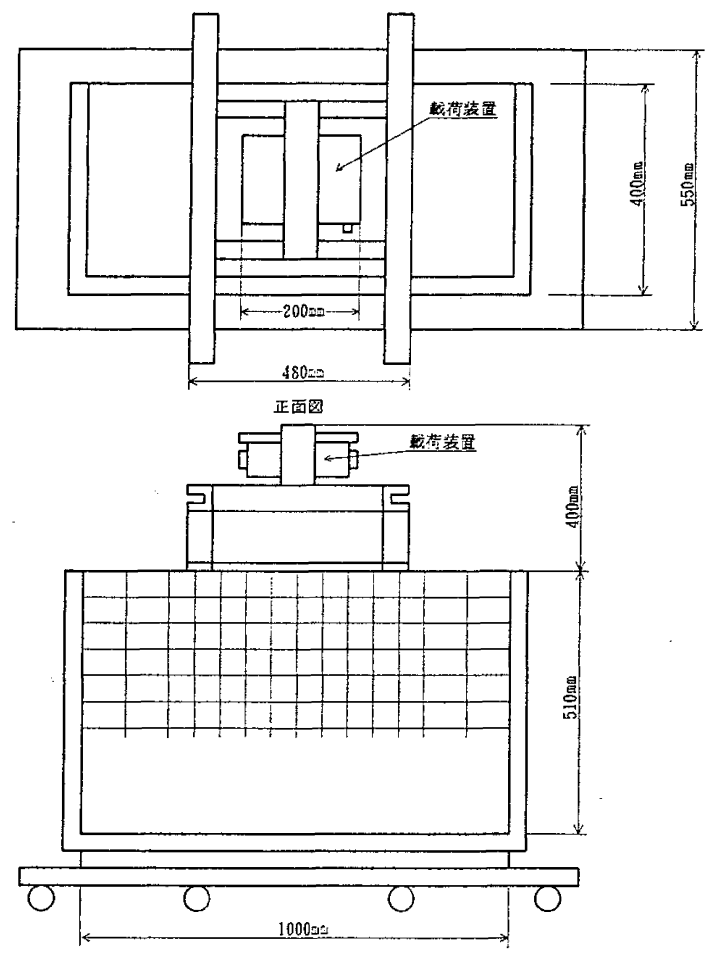

図-1 試験士槽 (Test I ， II ) 
えられるかして荷重による沈 下を可能な限り小さくするよ うに設計される。Terzaghiの 支持力理論に基づくシート工 法における盛土体の支持力要 素を分割して考えると次よう

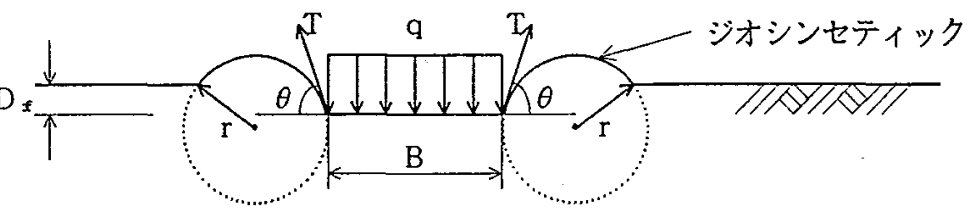

図-2 支持力機構の模式図

になる。

1) 在来地盤の支持力 $q_{1}$

2) シートの張力によるハ ンモック効果的支持力 $\mathrm{q}_{2}$

3）載荷体周辺のシートに よる押元効果 $\mathrm{q}_{3}$

4) 載荷体が在来地盤中に

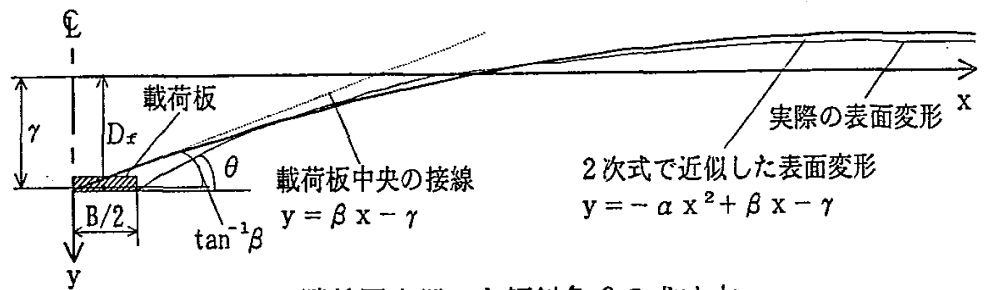
沈下した部分の押之盛土的支持力 $\mathrm{q}_{4}$

これらの支持効果を考慮することにより、Terzaghiの支持力理論を用いて軟弱地盤上の支持力機 構を考えることができる。すなわち、軟弱地盤上にシートまたはネット状のものを敷設して土を帯 状に一方向から載せていくと、盛土部分にめり込み量が生じてこのめり込み量に見合う体積とほぼ 同程度の土が盛土周辺に盛り上がって載荷と支持は均衡する。これらを次の式一1（Terzaghiの改 良型支持力算定法) ${ }^{4)}$ で示すことができる。

$$
q=q_{1}+q_{2}+q_{3}+q_{4}=c N c+\frac{2 T \sin \theta}{B}+\frac{T}{r}+\gamma_{t} D_{f} \cdots \cdot \cdot \cdot \text { 式 }-1
$$

ここで、 $\mathrm{c}$ : 軟弱地盤の粘着力, $\mathrm{Nc}$ : 支持力係数,

$\mathrm{T}$ : ジオシンセティックの張力に地盤との付着力を加えたもの,

$\gamma_{\mathrm{t}}$ : 軟弱地盤の単位体積重量, $D_{\mathrm{f}}$ : めり込み量,

$\mathrm{r}:$ 隣接円半径, $\theta:$ 傾斜角

また、図ー 3 は、実測表面変形とそれを 2 次曲線的変形と見なして 2 次曲線で近似した場合とを 比較したものである。これらの関係から、半径 $\mathrm{r}$ 抢よび傾斜角 $\theta$ は、式一 2 で示される。

$$
r=\frac{1}{2 \alpha}, \theta=\tan ^{-1} \beta \quad \cdots \cdot \cdot \text { 式 }-2
$$

\section{4、試験結果および考察}

\section{$4-1$ 摩擦特性試験}

図ー4は、Type Iによる摩擦試験の結果を示したのも である。粘土の初期含水比は、 $w_{0}=80,90,100 \%$ あっ たが、この結果から含水比の影響をほとんど受けていな いことがわかる。これは、粘土の含水比が高いため垂直 応力を載荷したときに粘土とジオシンセティックの接触 面に水分による膜ができたためと考えられる。また、各 含水比に抢ける付着力は、 $0.98,0.92,0.88 \mathrm{kN} / \mathrm{m}^{2}$ とな りかなり小さいことがわかる。

表ー3は、室内土槽モデル試験において表面変形にお けるジオシンセティックとカオリン粘土の付着力の影響 を調べるために行った試験結果である。

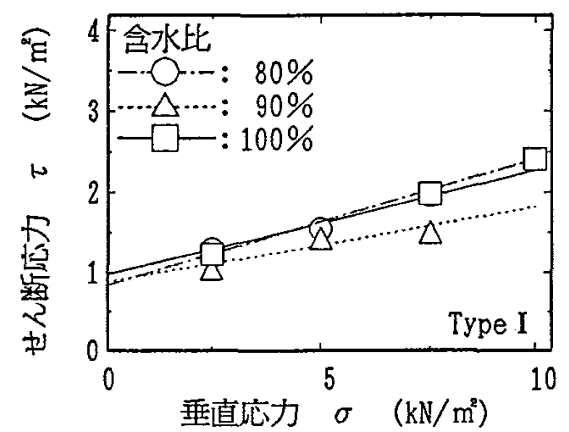

図一 4 ジオシンセティックと粘土の摩擦 
図一 5 は、在来型一面せん断試験装置 を用いて行ったカオリン粘土とジオシン セティックの付着力に及ぼすジオシンセ ティックの種類の影響を調べた結果であ 表一3 カオリン粘土とジオシンセティックの付着力 る。ジオシンセティック T-100, T-150， T-200における付着力は、それぞれ $1.7,1.3,1.1 \mathrm{kN} /$ $\mathrm{m}^{2}$ となり、今回の実験範囲ではジオシンセティックの引 張強度が増加するとカオリン粘土との付着力は、若干で はあるが減少する傾向にあることがわかる。

\section{$4-2$ 室内土槽モデル試験}

\section{$4 \cdot 2 \cdot 1$ Test I}

図一 6 は、 $\mathrm{T} \cdot 150$ 、載荷幅 $2.5 \mathrm{~cm}$ の場合の載荷荷重と 沈下量の関倸を示したものである。ジオシンセティック を敷設しない場合は、200N 以上載荷すると沈下が止ま らず貫入してしまう。しかし、ジオシンセティックを敷 設することにより沈下を抑制することができる。ジオシ ンセティックの両端に張力を与えた場合、張力の大きさ による沈下量の差異はあまり認められなかった。した がって、支持力は張力の大小の影響をほとんど受けない と考えられる。張力を与えず敷設のみの場合、載荷荷重 が300Nになるとジオシンセティックとカオリン粘土の 付着力のみでは耐えられず沈下量が大きくなる。また、 図示はしていないが載荷幅が $5.0 \mathrm{~cm}$ の場合は、 $2.5 \mathrm{~cm}$ の 場合に比べ大きな載荷荷重に耐 えられる結果が得られた。しか し、載荷応力で考えた場合は、 $2.5 \mathrm{~cm}$ の方が沈下量が少ない。 このことから載荷幅が小さい方 がジオシンセティックの張力に よるハンモック効果が発揮され ていると考元られる。

図一 7 は、 $\mathrm{T}-150$ 、載荷幅 $2.5 \mathrm{~cm}$ 、張力 $2.5 \mathrm{~N} / \mathrm{cm}$ の場合の 土槽表面および地盤内の変形を 例示したものである。表面より 深さ $300 \mathrm{~mm}$ を越えるとほとん

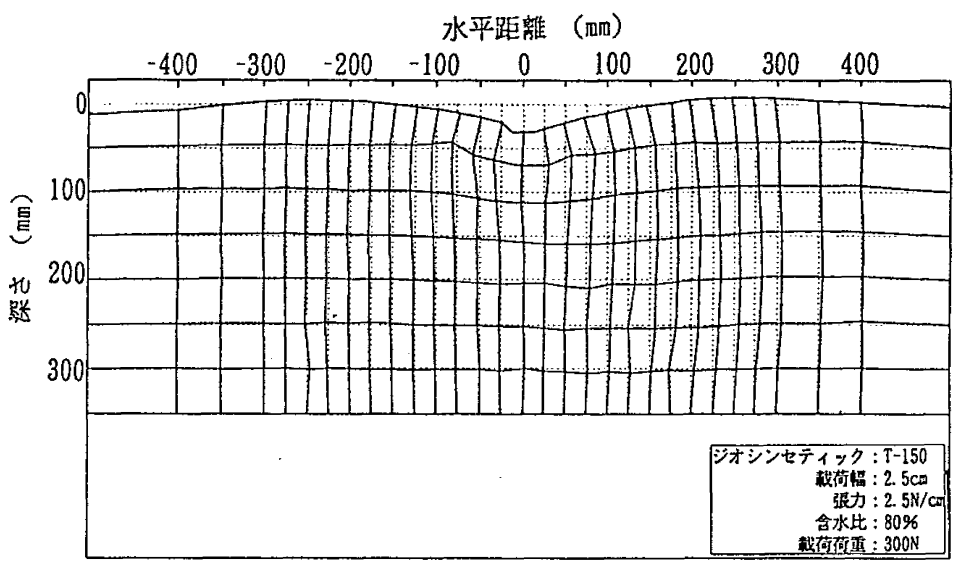

図一 7 地盤変形 (Test I )

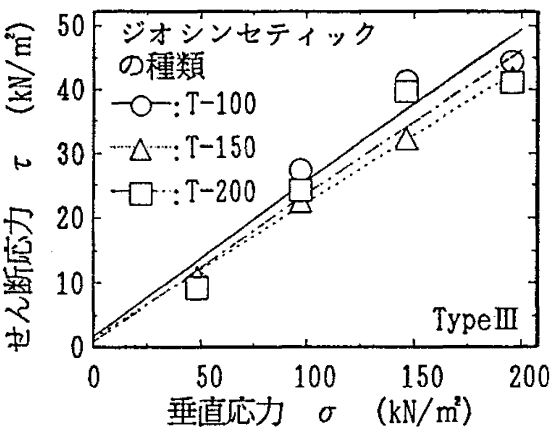

図一 5 ジオシンセティック之粘土の摩擦

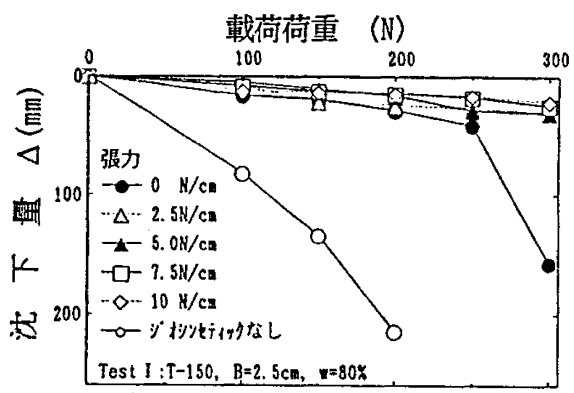

図一 6 載荷荷重一沈下量関係

ど変形を生じないことがわかる。また表面変形についてみるとジオシンセティックの張力および粘 土との付着力により2次曲線的変形を示している。これは、他の張力の場合も同様のことがいえる。

\section{$4 \cdot 2 \cdot 2$ test II}

図ー8は、表面に T-100を敷設、載荷幅 $5.0 \mathrm{~cm}$ のときの沈下量と載荷応力の関係を示したもので ある。この図から沈下量と載荷応力の間には、直線的な比例関係が見られる。また、ジオシンセ ティックを敷設するだけで敷設しない場合の約 2 倍程度の載荷応力に耐えることが出来る。しかも、 
ジオシンセティックに 張力を与えると、より 敷設効果を発揮するこ とがわかる。

図一 9 は、 $\mathrm{T} \cdot 100$ 、 載荷幅 $5.0 \mathrm{~cm}$ のときの 沈下量と載荷応力の関 係を敷設深さ別に示し たものである。敷設深 さが深くなるほど、耐 載荷応力が小さくなる

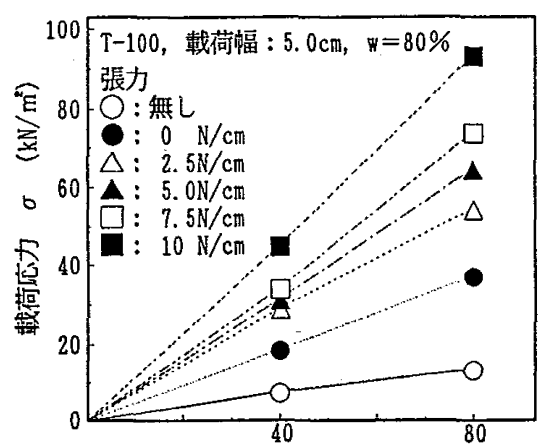

沈下量 $\Delta(\mathrm{mm})$

図-8 汭下量と載荷奻力の関係 (Test II)

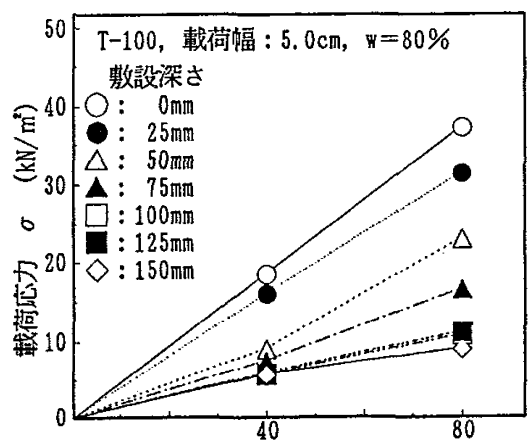

沈下量 $\Delta$ (min)

図-9 沈下量之載荷応力の関係 (Test II)

ことがわかる。また、敷設深さが $100 \mathrm{~mm}$ 以上になると載荷応力の差 が見られなくなり、敷設しない場合 とほほ同程度の值になり敷設効果が 発揮できないことがわかる。

図一10は、T-100に張力を $5.0 \mathrm{~N} /$ $\mathrm{cm}$ 与之、載荷幅 $5.0 \mathrm{~cm}$ のときの土槽 表面および地盤内変形について示し たものである。表面変形は、ほほ左 右対象であることがわかる。

図一 11 は、T-100を表面から $50 \mathrm{~m} \mathrm{~m}$ の深さに敷設し、載荷幅 $5.0 \mathrm{~cm}$ の場合の土槽表面および地盤 内変形を示したものであるが、この 場合も左右対象となり、貫入した周 辺以外はほとんど変形していないこ とがわかる。

\section{4-3 支持力補強に及ぼす影響要因}

（1）載荷幅の影響

図一 12 は、Test Iにおける載荷幅 と沈下量の関係を示したものであ

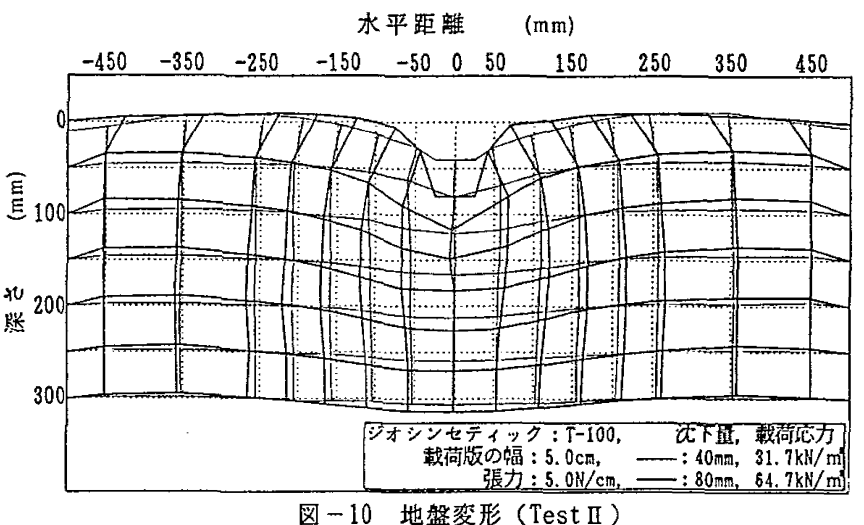

図 - 10 地盤変形 (Test II)

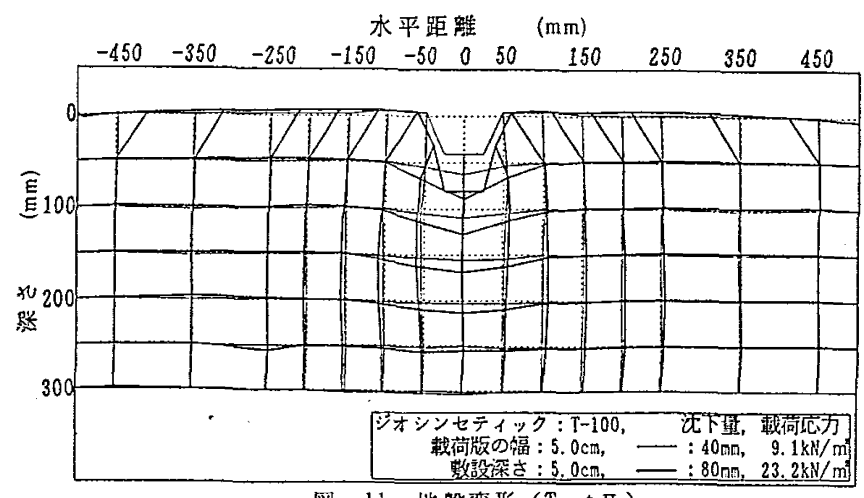

図 -11 地盤変形 (Test II)

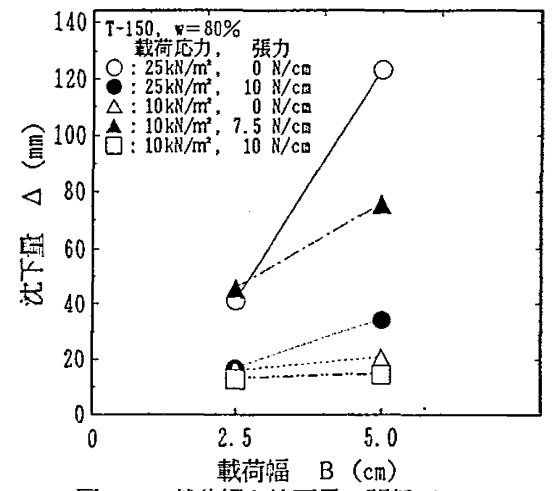

図-12 載荷幅と沈下量の関係 (Test I) 
よる押え効果 $\mathrm{q}_{3}=\mathrm{T} / \mathrm{r}$ は増加する。

図ー 14 は、 test IIにおける載荷幅と載荷空力の関係につ いて示したものである。載荷幅が増加すると載荷応力は減少 することがわかる。

これらより、沈下量制御で試験を行った場合、載荷幅が増 加するとジオシンセティックの張力によるハンモック的支持 力 $\mathrm{q}_{2}$ は減少し、載荷体周辺地盤のジオシンセティックによ る押え効果 $\mathrm{q}_{3}$ も減少することにより支持力は減少すると考 えられる。応力制御で行った場合は、載荷幅が増加するごと に沈下が増加するために、載荷体が在来地盤中に沈下した部 分の押え盛土的支持力 $\mathrm{q}_{4}=\gamma_{\mathrm{t}} \mathrm{D}_{\mathrm{f}}$ は增加し、ジオシンセ ティックの張力によるハンモック的支持力 $\mathrm{q}_{2}$ は隇少し、載 荷体周辺地盤のジオシンセティックによる押え効果 $\mathrm{q}_{3}$ は増 加する。

(2) 張力の影響

図ー 15 は、Test Iに扔ける載荷幅 $2.5 \mathrm{~cm}$ の場合の張力と 沈下量の関係を示したものである。張力が增加すると沈下量 はやや減少する傾向がみられる。このことをジオシンセ ティックの張力によるハンモック的支持力 $\mathrm{q}_{2}=2 \mathrm{~T} \sin \theta / \mathrm{B}$ について考えると、載荷幅が一定のため張力が增加すると $\mathrm{q}_{2}$ も増加するが、載荷体が在来地盤中に沈下した部分の押 え盛土的支持力 $\mathrm{q}_{4}=\gamma_{\mathrm{t}} \mathrm{D}_{\mathrm{f}}$ は、沈下量が減少することにより 減少する。また、図示はしないが張力と傾斜角の関係は、張 力が増加しても傾斜角は張力を与えない場合を除いてほとん ど差異は認められなかった。

図一16は、Test IIにおける載荷幅 $5.0 \mathrm{~cm}$ 、沈下量 $40 \mathrm{~mm}$ のときの張力と載荷㐫力についてジオシンセティックの種類 別に示したものである。張力が増加すると載荷応力も増加す る。 $\mathrm{q}_{2}=2 \mathrm{~T} \sin \theta / \mathrm{B}$ について考えると $\mathrm{q}_{2}$ は載荷幅が一定の ため増加し、 $\mathrm{q}_{3}$ も載荷幅が一定のため増加する。このことよ り、ジオシンセティックに張力を与えることにより支持力の 増加が得られると考えられる。また、張力と傾斜角の関係は 張力が増加すると傾斜角は減少する結果を得た。 $\mathrm{q}_{2}$ は張力 の増加率と傾斜角の減少率が関係するが押え効果 $\mathrm{q}_{3}$ は載荷 幅が一定のため増加する。このことより支持力式全体で考え ると張力の増加率の方が傾斜角の減少率より上回るため支持 力が増加すると考えられる。

以上のことから張力の影響について考えると、沈下量制御 の場合、張力が増加すると $\mathrm{q}_{2}$ は増加し $\mathrm{q}_{3}$ も増加する。この ことよりジオシンセティックに張力を与えることにより支持 力は増加すると考えられる。一方応力制御の場合は、張力が 増加すると $\mathrm{q}_{4}$ は減少し、 $\mathrm{q}_{2}$ および $\mathrm{q}_{3}$ は増加するがこの増減 量がほぼ一定のため支持力は変わらないと考えられる。

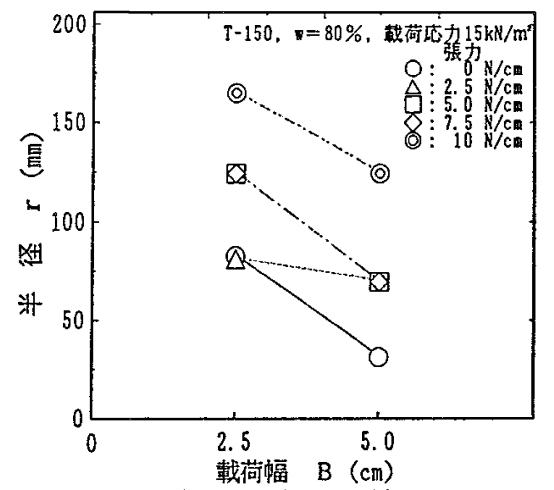

図-13 載荷幅と半径の関係 (Test I)

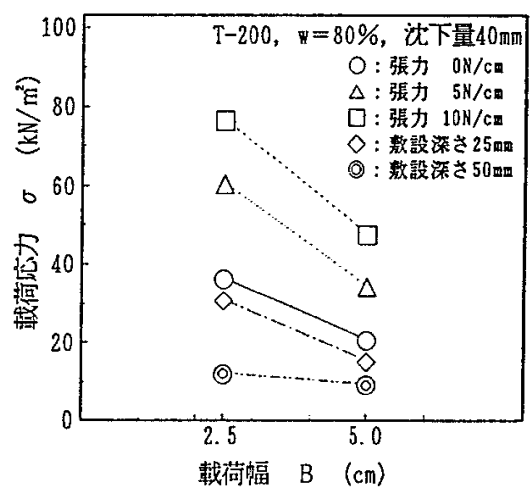

図-14 载荷幅と载荷纫力の関係(Test II)

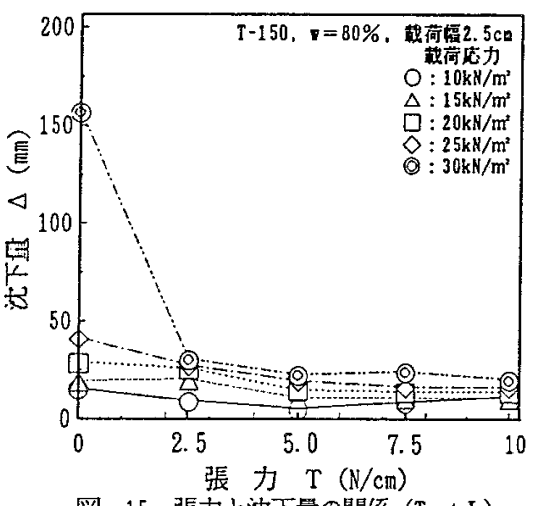

図-15 張力と沈下量の関係 (Test I )

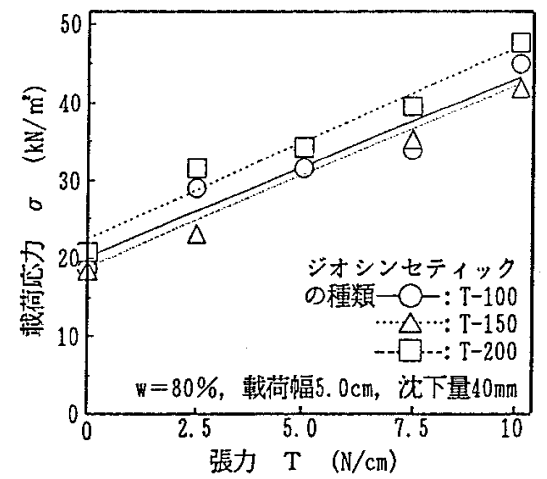

図-16 張力と䇝荷応力の関係(Test II) 


\section{(3) 敷設深さの影響}

図一 9 および図－17より一定以上深い位置 (ジオシンセティックの種類により異なる) にジオシ ンセティックを敷設しても敷設しない場合とほぼ同程度の載荷応力しか発揮しないことから軟弱地 盤内にジオシンセティックを敷設する場合、一定以深になると支持力の増加は期待できないことが わかる。

\section{(4) 押え効果の影響}

図一18は、Test IIに扔り張力と半径の関係をジオシンセティック別に示したものである。張力 が増加すると半径も増加していることから載荷体周辺地盤のジオシンセティックによる押え効果 $\mathrm{q}_{3}=\mathrm{T} / \mathrm{r}$ について考えると張力と半径の増加率を比較した場 合、張力の増加率の方が大きいので結果的には張力が増加す ると $\mathrm{q}_{4}$ は增加することになる。

(5) 諸パラメータ（傾斜角 $\theta$ 、半径 $\mathrm{r}$ )

図一 19 は、Test IIに打ける載荷応力と傾斜角について個 人差が生じやすい従来の方法と、表面変形を 2 次曲線的変形 と見なして求めた方法について比較したものである。両者は ほほ同様の減少傾向を示しているが表面変形を2次曲線的変 形と見なして求めた方が小さいことがわかる。また、四示し ていないが載荷応力と半径の関係は、2 次曲線的変形と見な

して求めた方が大きい結果となった。

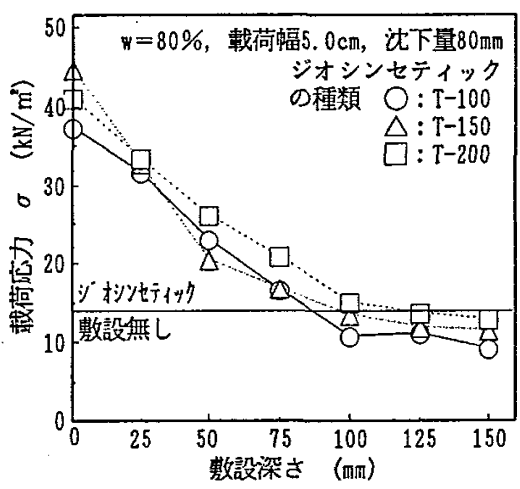

図-17 数設深さと䇝荷応力の関係(Test II)

4-4 Terzaghi $の$ 改良型支持力算定式

図-20〜21は、 Test IIにおいて従来の 方法と表面変形を 2 次 曲線で近似して求める 方について実測值と理 論值の関係を示したも のである。前者の方法 では、全体的に理論值 の方が過大評価し がちであるが、後者 の方は理論値と赛 測值がほぼ一致し ている結果を得た。 このことから表面 変形を 2 次式で近 似して求める方法 は、従来の方法より 適応性が高いとい 光る。

\section{5. 結論}

今回行った実験

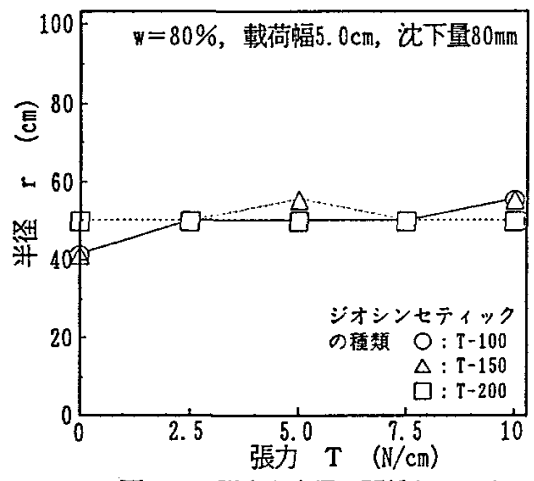

図-18 張力と半径の関係(Test II)

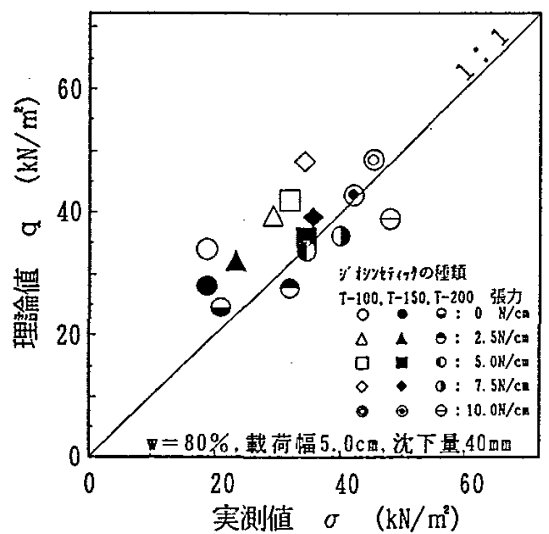

図-20 従来の方法で求めた実測値と理論值 の関係(Test II)

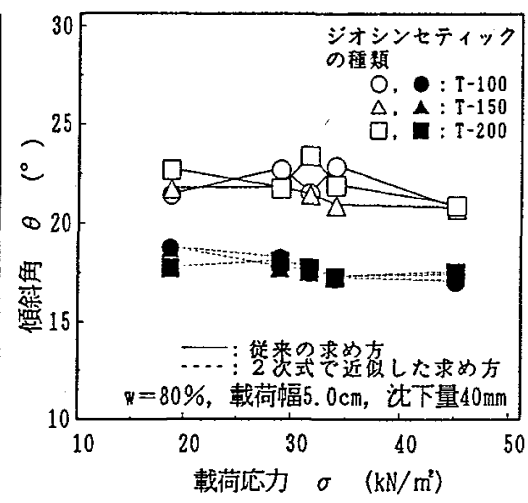

図-19 載荷灾力之傾斜角の関係(Test II)

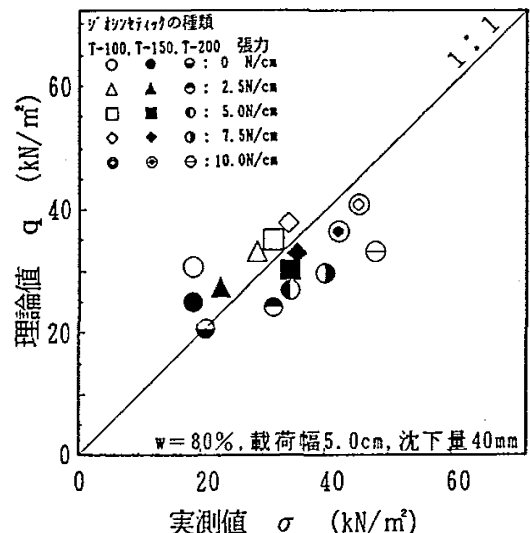

図-21 2 次式近似で求めた実測值と理論值 の関係(Test II) 
結果から次のような結論を得た。

1) Terzaghi の改良型支持力算定式において、表面変形を 2 次式で近似することにより、従来の 方法に比べ半径 $\mathrm{r}$ および傾斜角 $\theta$ の算出を個人誤差の影響を受けず行うことができる。

2) ジオシンセティック敷設による支持力 $\mathrm{q}_{2}$ は、今回の実験結果では全支持力の約 7 割程度を占 め、ハンモック的効果が大きいことがわかった。また、ジオシンセティックの張力と地盤との 付着力を加えたものを張力とするため、ジオシンセティックと地盤との付着力が大きな影響を 及ぼす。

3) ジオシンセティックの敷設深さは、ジオシンセティックの種類に関係なくある一定以梁にな ると支持力の増加は期待できない。

\section{【参考文献】}

1) 土質工学会：土質工学ハンドブック, pp.323-341, 1982.

2) 土質工学会：土質試験の方法と解説, pp.319-235, 1990.2 .

3） 前田工繊(株)：試験結果報告書, 1993.4.

4）土質工学会：補強土工法, pp.325-329, 1986.

\section{【謝辞】}

本研究を行うにあたり、本学大学院生久保崇紀 (現：J R 東日本(侏))、光吉勝 (現：谷本臨海土木 (㧣) 両君の協力を得た。また、前田工繊侏にはジオシンセティック試料の提供を受けた。このこと をここに記し謝意を表します。 